\title{
Management of students crisis in higher institutions of learning in Nigeria
}

\author{
Onyike Maggaret Odu \\ Department of Educational Foundations, College of Education, Oju, Benue State, Nigeria
} Phon: 8062375169 or 08070666631

E-mail address: odu.margaret@yahoo.com

\section{ABSTRACT}

This study was intended to investigate factors that characterize campus crin and uggests way forward with the aim of maintaining crisis free institutions. Two r all theses we formulated and tested for the study. The results of this study suggest that: tyo asons ld be responsible for not meeting the demands of the students. First is the high pop ratu of studo match the available facilities, students' demands and the attitudes of some athorities who refy se to listen to students' request. Secondly, lack of essential facilities in campuses ause students' crisis in higher institutions of learning in Nigeria. Based on the findings, cultism, o munication gap between authorities and students' representatives, hyper-patriotic youthful exubera in dev ating from behavioural norms of the society and students' home background are causes or students' crisis in higher institutions in Nigeria.

Keywords: campus; student; higher in ions; $\mathrm{Ni}$ r ria

\section{INTRODUCTION}

The current ${ }^{+}$ucation in education sector in Nigeria in the areas of planning, curriculum in ovatio and teag ed education among others are management mechanism to revamp edv in in atry to instill discipline in various institutions of learning. Government on her own sic ntroduc $d$ the free education scheme and bursary award for students of tertiar. ution le aning.

Gove hment to $k$ these strides to enhance equal educational opportunities. The efforts of go w withstanding, there have been increase in students' crisis in almost all the higher itutions of learning especially in Nigerian universities. Crisis in Nigerian higher institution not a welcome development. Rather it is cankerworm, hydra headed, disturbing to parents/guardians and citizens of the nation. Akinade (1993) showcased students' crisis in Nigerian Universities between 1970 and 2005.

The scenario is illustrated below:

a. Ahmadu Bello University, Zaria in 1970, the crisis was as a result of inadequate feeding and accommodation.

b. University of Ibadan in 1971, students requested for the removal of a catering officer, the incident resulted in the death of a student. 
c. University of Ibadan in 1974, some students lost their lives for demanding the removal of catering officer.

d. Ahmadu Bello University, Zaria in 1978, over an increase in school fees which resulted into nationwide demonstration by University students.

e. Obafemi Awolowo University in 1981 over a beheaded undergraduate student (loss of life).

f. University of Nigeria, Nsukka 1981, over inadequate infrastructure.

g. Ahmadu Bello University, 1986 over high-handedness by the university authority.

h. University of Lagos, 1987 over imaginary white paper to expel a student leader anent of unrest in ABU.

i. University of Jos, 1988 protest over government removal of oil subsidy.

j. Obafemi Awolowo, Ife, Ilorin, Abeokuta Universities, 1991, over the refus o yield students demand.

k. Lagos State University 2002 - brutal murder of a union leader.

1. Ebonyi State University, 2004 crisis over bad road leading to I

m. Lagos State University, 2002 - brutal murder of union leade

Students' crisis in the institutions of learning conct tes a voc as it often lead to temporary closure of the institution, boycott of lecture sus, ension axpulsion of students and student leaders, loss of lives, damage of s hool properties, disruption of school administration and truncation in academic progran es of the university. (Sanya, 1981 and Aminu, 1988).

Cultism as one of the causes of students' crisis i who share unconventional ideas, and beliefs rolve themselves in eccentric conduct and manifestation mostly shrouded in secrecy; c ry oun cret cult activities and membership, organization, rules and mode of oparation are supposed to be unknown and unknowable to non-member cult (Umeh $2001 \mathrm{a}$ a Ty o 2002) Infighting and internal wrangling by cultists led to the formation of spinste uups auch as S adogs, Buccaneer confraternity, the Vikings, the Black Beret, the Daugh o ceur.wong others (Egwu, 2003). Impulsive desires for supremacy are among reasons hind cult clashes, murder, maiming, rape, acts of sickening and barbari m ur institut ns of higher learning (Umeh, 2001).

Some of th sures of campus secret cults in Nigerian universities are nocturnal meet igs beld at od a aces like cemeteries, hilltops or forests, knife and dagger pulling, gun quin nan-members or members of opposed campus secret cults; torture, distinctive man the b ly; drinking human blood and others (Nwanze, 1991 and Igodo, 2002) pra es, ase of hand drugs, violence, ritual killing are modus operandi of secr cul Onyeh (2002:34) reported that suspected, cultists once moved into the Un vity campus in a convoy of three cars "shooting endlessly at studen vid to be in the middle of an examination, sixteen of who were felled instantly.

Mis $y$ done, the attackers then speed off to escape, fatally wounding two other persons bri iging the death toll to eighteen. According to him, the attackers were unleashed by the Viking confraternity in revenge for an alleged killing of their two members by the Buccaneer. In another similar incidence in 2003, Ebonyi State University recorded the death of six students; massacre of five students union leaders of Obafemi Awolowo University, IleIfe in 1999 and the brutal murder of students union leader of Lagos State University in 2002 (Igodo 2002). Consequences of these nefarious act lead to indefinite closure of the institutions which the university authority cite as insecurity of lives and properties as reasons for the indefinite closure against cultism. Cult menaces in our institutions of higher learning are 
gaining momentum daily taking more dangerous dimensions and in fact, running a parallel government with the university authorities. Measures targeted at stemming the menace of cultism in institution of higher learning appear not yielding positive fruits.

Another fact that aggravate students' crisis in Nigeria universities is communication gap. Effective communication diffuses tension among students and authorities in the institution. Despite this fact, some authorities of Nigerian universities shut their administrative doors to students' complaints and grievances which may likely result to students registering some unacceptable social behaviour such as violent demonstration of 1981. Ezike (1993:6) stated some psychological consequences of shutting adminictrative doors on students' complaints and requests when he remarked, "they feel th processed by a system to which they strongly object but are powerless change."

When students are denied the opportunity of being part of polic making a sion in related matters of their welfare they feel subjected and dehumanizer Stude belic they should have significant voice in determining some issues patternin tho "clfare. Shen they ask to be heard and refused being heard and when legitimate channels clocd there is bound to be crisis. When students' body or representatives a coluded fron articipating in the deliberation on issues that significantly influence their ucati objectives, a feeling of isolation and ostracism is created. Malevolent transf ontm ion of $\mathrm{ing}$ of living among enemies is also created. This increases the probabili es of constant st)dent-authority clashes in universities. Effective communication diffused to ion betwee students and authorities in the institutions.

Youthful exuberance especially the nerative chan s is another serious issues that spark off students' crisis in our institution social irrelevance of youth behaviour, confrontation, victims of inte ectrance, emotional instability are characteristics of adolescents which-when ov -stretched results to disastrous consequences such as riots and demonstration , OKu , 1983, Ufot 1980 and Refus 1980). Anowor (1983) observes that increase in phy ch acteristics of the adolescent often push them to over react. He compared their y wu "ucram lo active volcano."

That is, they ceas every opp unity to display their strength and often do so in the wrong place, against ro erson as y esult of misplaced aggression. Anowor's comparison is evidenced in a pression when students of the Federal Government College, Otukpo in 2005 beat up an in rator and set ablaze a car belonging to another invigilator because the vigilat insisted that students should write their first semester Mathematics examinations ut chea $\mathrm{dg}$.

Ebor Stat University students in 2004 while protesting against poor condition of $r$ ad lea ng to Is cke campus, they organized and barricaded the express road leading to Aba iki micked traffic movement and destroyed goods running into millions of naira. In the ds of Wale (1982:25) he attributed those negative attitudes to students' immaturity and with adant energy and their belief that all scores should be settled violently. He reported "Moslem students in Kano municipality trooped out to destroy a Church.

Their grouse was that the Christian Church was too close to a Mosque." Anything and everything is capable of arousing sentiments and wraths of students to warrant an unguided outpouring into the streets to protest concluded (Abdulahi 1991). Home background of students to some extent dictates the quality of students' behaviour at a stage in life. Students as products of the home their behaviour reflect the nature of their homes. Some undesirable behaviour of students directly or indirectly leads to students' crisis such as intimation, assault 
and insult, wanton destruction of property, participation in secret cults, drug offences, lesbianism, Anadi (1993) observed.

Students' crisis is worrisome to parents, government and even the students' themselves. Crisis in schools lead to closure, suspension disruption in academic calendar. Authorities cannot predict how long a semester or academic year could last (five or six years) depending on frequency of students' crisis.

The situation is a serious challenge. The need to maintain crisis free system provided the motivation for the study. It was also the aim of the study to investigate factors that characterize campus crisis and suggest way forward.

The following two null hypotheses were formulated and tested for the study

$\mathrm{HO}_{1}$ There is no significant difference between the opinion of male and formale students on the causes of students' crisis.

$\mathrm{HO}_{2}$ There is no significant difference in the mean rating of stude ts management strategies of students' crisis.

The study whose scoped covered Ebonyi and Eny Sta limited to causes and management strategies of students' crisis. It is conside eur gnifican many ways. There is no doubt that the study will provide database to auth rities in tertiary i stitutions on students' crisis management, policymakers and guide future $r$ earchers.

\section{METHOD OF STUDY}

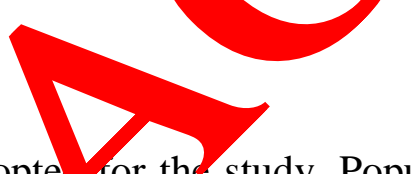

A descriptive survey design was adopte for the study. Population of study comprised 60,800 students in tertiary instity cons Ebony ind Enugu States.

The sample for the stud as 6 .00 stude its selected through simple stratified random sampling technique. Dat or sum were collected using a questionnaire titled Management of Student Crisis (M.

The questionnz e validated y experts in educational administration/Management. A pilot study to denaine th vel of reliability was carried out on 20 students of Abia State University who were not part of study within a time interval of two weeks using Cronbach reliability te hat yi an alpha value of $0.81(\mathrm{~N}=20)$.

The inst nts use for data collection were administered through research assistants. The dat an ang t-test statistical difference.

\section{RE TTS AIND DISCUSSION}

$\mathrm{HO}_{1}$ The is no significant difference between the opinion of male and female students on the causes of students' crisis in higher institution of learning.

Hypothesis 1 was tested using t-test. The result of the analysis is shown on Table 1 below. t-test analysis showing differences expressed by male and female students. 
Table 1

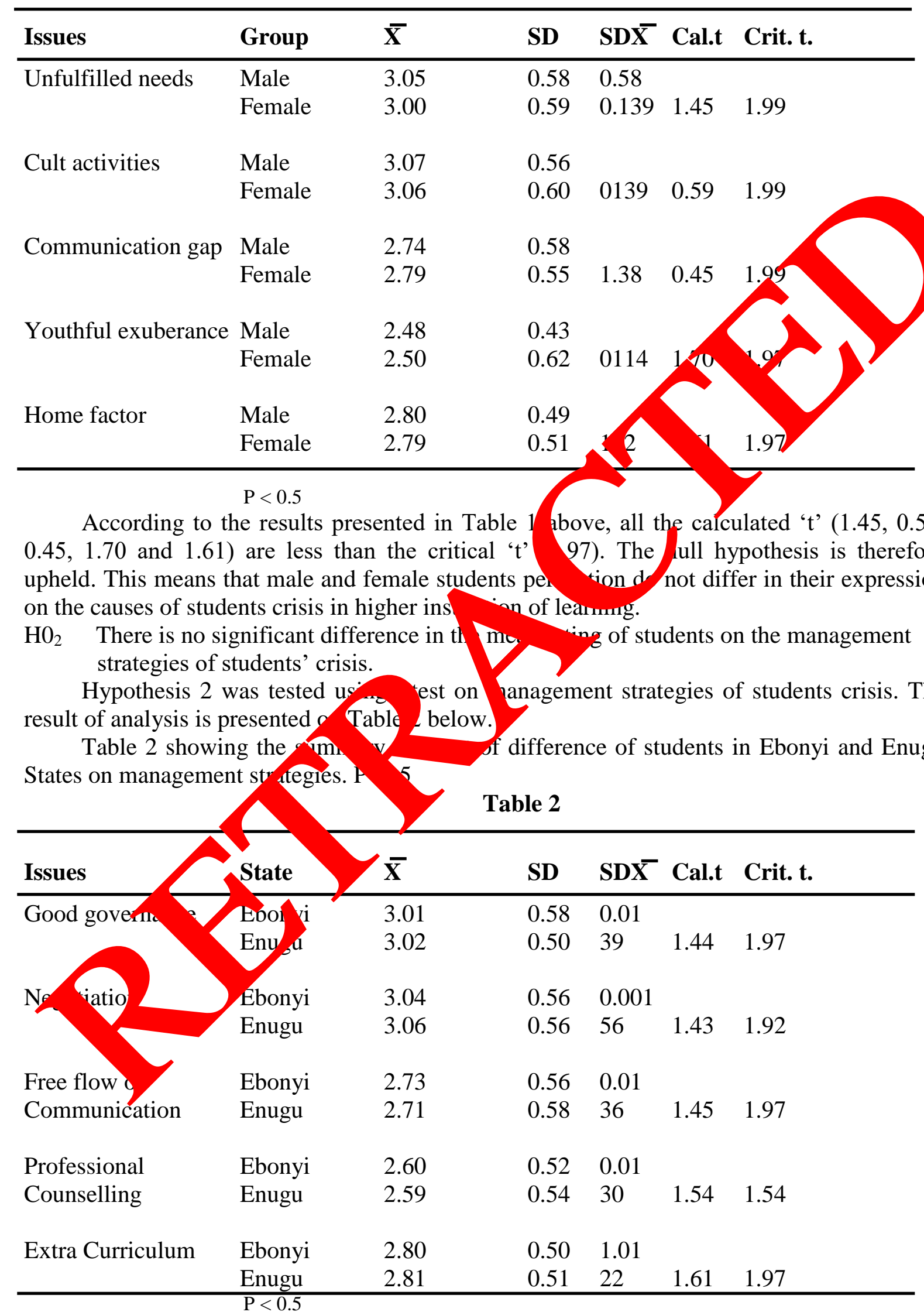


According to the data shown above in table 2 at 0.05 level of significance, the calculated ' $t$ ' $(1.44,1.43,1.45,1.54$ and 1.61) are less than the critical ' $t$ ' value (1.97) it was therefore accepted as conflicting management strategies by the two States.

\section{DISCUSSION OF FINDINGS}

On the student demands, two reasons could be responsible for not meeting First is the high population of students to match the available facilities, studep demand a the attitudes of some authorities who refuse to listen to students' requents. vever, $t$ finding of inadequate facilities agree with Onyecherelam (1983) who stomitted th lack of essential facilities in campuses cause students' crisis in higher in rutions f lear in in Nigeria. One must not forget that hierarchy of needs (water, light aco rodation must be met to attain a state of congruence because these are necessary or the sur of of tudents on campus and most especially for the promotion of positi e haviour in the social
environment.

Again, violent secret cult activities as another nraj cause cudents' crisis was attributed to the intent to eliminate their rivals, co trol campus poljacs or students union government. Echezona (2001) described some of cult mem"ers as academic never-dowell. The introduction of post screening test by un rsity autb orities is a good managerial technique that is likely going to stamp out or redu 1. ctivities, as academic-minded students will be selected for admission. Co ation gap also influences students' crisis, the finding revealed that students in most cas $\mathrm{s}$ f n complaints through proper channels to air their grievances. Some maion-decision on students' crisis lay with the institution's Senate Council without been im rem ed. Add d to this is lukewarm attitude of some of the school authorities to respond tude its' compraints and sometimes complaints are treated with slash or silent repro? Un sity andorities should endeavour to be good listeners. Rioting and destruction f properti re, ways of youth crisis (youthful exuberance). Most students are in their ar. dolescent lage with their attendant problems. Some choose to champion cases enteral to $m$. Instance of this is University of Nigeria, Nsukka (UNN) students' demo stration over a electricity blackout in Nsukka. The finding of youthful exuberance vee w Okeke (1996) and Anowar (1993) who observed that adolescent possesses revo nary an reformist zeal and can deviate from behavioural norms and even go extr les in pusuit to remedy some ills of the society.

\section{MA GEMLNT OF STUDENTS' CRISIS}

Students' crisis of any magnitude in higher institutions of learning in Nigeria is abnormal, dysfunctional and detestable. Crisis is an extreme situation of conflict to a point of extreme violence that is, threat to human security, fighting, death, injury, etc. (Gaya 2006). These are characteristics of students' crisis in our institution of learning as earlier itemized. But for Burton (1990) crisis can always be resolved, what the practitioners can do is to manage and regulate them. Some of the management strategies that school authorities should practice include: 
a. Good-governance: Good governance is the process of crisis prevention through proactive measure of running the affairs of the institution in positive and progressive manner beneficial to students, listening to students' complaints, being transparent, democratic as opposed to autocratic and dictorial. Good-governance diffuse tensions and remove problems s they evolve (Gaya, 2006).

b. Clarification of communication: This takes the form of both parties avoiding harmful statement, looking for flexible 'shade of gray' solution, identifying conflict issues during negotiations. Otite (1990) remarked that use of appropriate communication skills and channels are crucial in crisis management.

Exchange and sharing of accurate information can as well help to remo e doubts suspicions by students that their complaints are not being looked ino the scho authority.

c. Negotiation: Negotiation as a structured process of dialog bety an cor cting parties attempts to reach an agreement through joint decisig a shor this managerial skill, as "loopholes" therefore, should $n$ of be con "tatio al in their demands. Students should as much as possible compr that is concessions
in order to resolve crisis.

\section{CONCLUSION AND RECOMMENDATION}

Based on findings, the study concludes that communication gap between authorities and students representative, hype iotic youthful exuberance in deviating from behavioural norms of the society and student hom ground are major causes of students' crisis in higher institutions in Nigeria. The p er alse concludes that good governance and dialogue are the most basic meth oas crisis is anagement and prevention. Again, indefinite closure of institution and exp in o students as a yardstick against students' crisis should be sparely used as a correct and recommends that:

1. School authorit hould as as possible observe transparency in their dealings with student be active, lsten to complaints and above all be democratic as opposed t Itocracy 11 matters affecting students' welfare.

2. All ne essar informaty concerning students should be sold to them through the insti ns ouse organ such as information bulletin newsletter and magazines.

Informa should $\delta$ free and clarified; exchange and shared as it will remove doubts
cris emanat $\mathrm{g}$ from communication gap. cris emanat $g$ from communication gap.

3. Suld be less confrontational in the demands and it is only in extreme cases suppression as management skill be used as the instrument of power and force to pus aray issues pertaining to students under the carpet or impose solution that is not sustainable.

4. The use of negotiation as a process of dialogue was also recommended. Conflicting parties should attempt to reach an agreement and take joint decision that will assist in resolving crisis.

5. School authorities should establish functional professional counselling units in all institutions of higher learning to provide counselling and psychological services to students to reduce behavioural activities that run counter to societal and institutional expectation. 
6. Finally, responsible students should be nominated to serve in committees (e.g. disciplinary committee) and indirectly use them as informants to school authority to timely inform management when students plan riot or intending to take laws into their hands.

\section{References}

[1] Abdullahi A. (1991). Why 6-3-3-4 system is not working. Daily Times 12 March 1091. P. 12.

[2] Akinade E. A. (1993). Guidance and counselling strategies for prevention ntrolling

[3] Students Activities in Nigerian Tertiary Institutions in O. Animba, D Denga an Omolabi, (eds.) Appraisal of students' unrest in Nigeria. Enugu: A IC pu 'ishers.

[4] Aminu J. M. (1988). Only president can reopen universities. D 20.

[5] Anadi G. C. (1993). The problem of indiscipline in Nig ia: 1 home fachor in O. [6] Animba D. Denga and O. Omolabi (eds.). Apprais ror sudents' 4 in Nigeria.
Enugu: ABIC publishers,

[7] Anowor O. O. (1993). Adolescence and its impl tion for im rovement of students.

[8] Discipline in O. Animba, D. Denga, ane O. Omola Appraisal of students unrest in Nigeria: Enugu: ABIC publishers.

[9] Burton J. W. (1990). Conflict resolution a d reve, con. London: Macmillan.

[10] Echezona I. (2001). Curbin sea cults-r ated crisis in Nigerian Universities.

[11] A.U. Akubue, D. Enyi ea Cr. Wisdom Publishers $1 \mathrm{a}$.

[12] Egwu E. (2003) io oht: Towa s exposing and eradicating cult and other social vices on camnu Lago Qravo Nominees Ltd.

[13] Ezike H. (1903). Root ase and remedies of indiscipline in Nigerian universities in O.

[14] Aniamba $\downarrow$ enga. Omolabi (eds.) Appraisal of students' unrest in Nigeria: Enugu:

ABI Publish

[15] The methods of conflict resolution and transformation in Gaya, S.B. (a Introduction to peace and conflict studies in West Africa. Ibadan: Spectrum Books Lim,

[16] Igodo C. (2002). Campaign against cultism and drug abuse among youths in Nigeria. Enugu: Magnet Business.

[17] Nwanze S. (1991). Unveiling the secret of secret societies in campuses. National Concord, Lagos. $18^{\text {th }}$ April, 1991. P. 16-18.

[18] Okoye N. N. (1993). Psychological techniques for handling campus indiscipline in our institutions of higher learning in O. Animba, D. Denga and O. Omolabe (eds.) appraisal of students unrest in Nigeria. Enugu: ABIC publishers. 
[19] Okeke V. U. (1996). Factors affecting students' crisis as perceived by the staff and students of UNN. Unpublished M.Ed. Thesis. October 1996.

[20] Olanrewaju K. (2003). I have lost a gem. The Cornet Newspaper (Lagos) $28^{\text {th }}$ August, 2003. P. 3.

[21] Onyecheralam C. A. (1983). A study of cases of students' unrest as perceived by students in selected secondary schools in Imo State. Unpublished M.Ed. Thesis June 1983.

[22] Onyeka B. V. (2002). Morning Madness at UNN. The Guardian (Lagos) $22^{\text {nd }}$ June 2002. P. 24.

[23] Otite O. (1999). On conflict, their resolution, transformation and manage In O. Otite (ed.). Community conflicts in Nigeria Ibadan: Spectrum Books $d$.

[24] Rufus I. (1980 May, 21). Dealing with students' unrest. Daily Tip es. 1(3 4), 10.

[25] Sanya O. A. (1981, May 2). Decade students' unrest. Sunday ono 1 (413)

[26] The Guardian (2002). Cultism and violence on our camp The Gua vo (Lagos) March 2002. P. 22.

[27] Ufot O. A., Journal for Education Practitioners a a 1 1(5) (1980) 35-38.

[28] Obi E. (1997). Communication and manageme of organiza ion behaviour in A.N.

[29] Ndu L. O. Ocho and O. Okeke (eds.) Dvnamic on nal administration and management. Awka: Makes publishers

[30] Umeh E. D. (2001). Tertiary institution i Neria naven or coven. Enugu: Pan African publishers.

[31] Wale A. (1982). Forty-fo confi hed deac in Kano and Kaduna. Daily Times (Lagos) $4^{\text {th }}$ November, 1982. 